\title{
Gender Equality Education in Social Studies Learning at State Junior High School 15 Yogyakarta Indonesia
}

\author{
Yuhanida Milhani ${ }^{1}$, Supardi ${ }^{2}$, Satriyo Wibowo ${ }^{3}$ \\ 1,2,3 Department of Social Science Education Yogyakarta State University, Indonesia \\ 1yuhanida@uny.ac.id,2pardi@uny.ac.id, ${ }^{3}$ satriyo@uny.ac.id
}

\begin{abstract}
This Education is not just a learning process but it is one of the "sources" for all knowledge including related values with that issue. This education is also a means of socialization culture that takes place formally including in school. However, this matter not followed by the promotion of gender equality and gender equity educational institutions. Educational institutions in Indonesia still reflect gender inequality. Education in Indonesia still occurs practice gender based discrimination. Such discriminatory practices can various types, including physical, psychological violence, negative stigma, and marginalization. Social Sciences as one of the subjects in the SMP curriculum is the right place to be able to integrate education gender equality in the learning process besides Civics subjects. During there is a lot of assumption that social studies is only a more memorized subject, whereas when viewed from the learning objectives, IPS aims to develop students to be more sensitive to social problems which occurs in the community, has a positive mental attitude towards improvement any imbalances that occur and skilled at overcoming every problem that occur everyday both those that afflict themselves and those that afflict them society, one of which is about the issue of gender equality. The institution education that has realized gender equality and justice is SMP Negeri 15 Yogyakarta. One of the visions of Yogyakarta 15 Public Middle School is "Realizing gender responsive schools" and further elaborated through its mission "balancing the specific needs of students (gender responsive). The purpose of this study is to determine implementation gender equality education in social studies learning in SMP Negeri 15 Yogyakarta This research method uses descriptive qualitative research. Data collection techniques in this study were observation, interviews and documentation. Data presentation techniques use descriptive and examination The validity of the data uses triangulation. Data analysis techniques in research this uses interactivity analysis. The result show that The implementation of gender responsive schools in social studies learning at SMP Negeri 15 Yogyakarta has four standard components, namely (1) gender responsive school content standards in social studies learning, (2) gender responsive school process standards in social studies learning, (3) school classroom structuring standards gender responsive in social studies learning, and (4) gender responsive school assessment standards in social studies learning.
\end{abstract}

Keywords: gender equality education, social studies

\section{Introduction}

According to Nugroho (2008: 8) gender can be interpreted as a distinction between the roles of women and men in which social and cultural constructions are formed, not brought from birth (biological). If "gender" is something that is born (biological), then "gender" is something that is formed due to an understanding that grows and develops in society. For example, women are in charge of raising and caring for children while men work to earn a living is a "gender" distinction. 
Understanding of gender can be formed through gender relations, which results in gender relations between men and women. Remiswal (2013: 1) states that the millennial era demands major changes related to gender relations, namely a relationship that requires equal roles between men and women in the life of society, nation and state. The demand for equality of roles can be seen as a form of necessity that accommodates the level of community participation and eliminates the domination of men over women in development. The existence of a form of role domination that has occurred so far can be the cause of the low participation of women in the public sphere. This condition is not favorable for women who have a strategic role in life such as in educational development and so on. However, in every place and area the existence of gender is influenced by various factors including ecological, social and cultural factors. These factors cause frequently differences in responses to gender, causing various irregularities that can lead to gender injustice and inequality.

Nugroho (2008: 17-18) states that gender injustice is manifested in the form of marginalization, subordination, violence, stereotypes and workloads that have occurred at various levels in society. First, the manifestation of gender injustice occurs at the state level, both in one country and in organizations between countries. Many state policies and laws, legislation and activity programs still reflect some forms of gender injustice. Second, the manifestation of gender injustice also occurs in the workplace, organizations and in the world of education. Many work regulations, management, organizational policies, and educational curricula still perpetuate this gender injustice. Third, in the customs of many ethnic groups in society, ethnic culture as well as in religious interpretation, this form of gender injustice also occurs. Many interaction and decision-making mechanisms in society still reflect gender injustice. Fourth, gender injustice also occurs in the household environment. Starting from decision making, division of labor, to interaction between family members. Thus the household becomes a critical place in the socialization of gender injustice.

Law Number 20 of 2003 concerning the national education system mandates that the implementation of education is obliged to hold several principles, namely that education is carried out in a democratic and just manner and is not discriminatory by upholding human rights, religious values, and the diversity of a nation. This law clearly shows that education must be carried out fairly, democratically, and taking into account the diversity that exists in Indonesia.

Just education can be realized if there are aspects that must be fulfilled, one of which is gender equality. Remiswal in his book Evoking Menggugah Partisipasi Gender di Lingkungan Komunitas Lokal (2013: 7) states that gender equality is a form of equality between men and women in family, community, national and state life. The various roles constructed by the socio-cultural community should be free from acts of discrimination, so that men and women have equal chances and opportunities in appreciating their rights and obligations. Rights and obligations are something that are closely attached to the potential possessed by individuals, with gender insight, the parallel between men and women in all aspects of life is a form of manifestation of human rights as social and cultural beings.

Gender problems in education in Indonesia can be seen from the Central Statistics Agency (BPS) data report which states that the Gender Development Index for the average length of schooling for girls from 2010-2018 is 7.27 years and boys are at 8, 25 years (www.bps.go.id accessed on 29 November 2019 at 14.10 WIB). It can be said that if the value of the Gender Development Index is higher, the gender education is getting better, and vice versa. This Gender Development Index can be a measure of the success of education in promoting gender equality and justice in Indonesia. 
Education is not just a learning process but is one of the "sources" for all knowledge including values related to the issue. Thus education is also a means of cultural socialization that takes place formally, including at school. However, this was not followed by the socialization of gender equality and gender justice in educational institutions. Educational institutions in Indonesia still reflect gender inequality. Education in Indonesia still occurs in discriminatory practices based on gender. Discriminatory practices can take various forms, including physical, psychological violence, negative stigma, and marginalization.

Muawanah (2009: 54) states that there are three aspects of gender problems in education that cause inequality. The first aspect is access, which is related to educational facilities that are difficult to reach. The second aspect is participation, which is covered in the field of education studies and statistics, the large number of women who take the field of teacher training (for example, Teacher Education Schools) because of the view that the role of teachers is as coaches. also caregivers are described as the nature of women as mothers, therefore $99 \%$ of teacher education schools are attracted to women (being junior secondary teachers) and $99.5 \%$ of STM are attracted by men, and TK teachers are mostly women, this is influenced by gender stereotypes. The third aspect is the benefits and mastery of reading skills, this is related to the number of illiterate people who are dominated by women.

According to Muawanah (2009: 54) gender bias in education can be seen in compulsory reading books in schools, most of which transfer gender values or norms that apply in society's culture. This means that the gender value system will affect the life of the social system at school. For example, in textbooks, the gender roles of women and men are constructed in segregation, fathers / men are depicted working in offices, in gardens, and the like (public sector), while women / mothers are portrayed in the kitchen, cooking, washing, take care of younger siblings, and the like (domestic).

Gender bias in education is also explained by Muthalib (Amir, 2013: 16). In textbooks, there are many pictures and sentence formulations that do not reflect gender equality (gender bias). For example, the image of a pilot is always male because the job as a pilot requires skills and strengths that only men have. In addition, sentences such as "This is Budi's mother" instead of "This is Suci's Mother", "Father reads the newspaper and Mother cooks in the kitchen" and not the other way around "Father cooks in the kitchen and Mother reads the newspaper", are still often found in many textbooks or even examples of sentence formulations delivered by the teacher in the classroom. The formulation of the sentence reflects the feminine nature and domestic work for women as well as the masculine nature and public work for men. Murfi (2014: 280-281) states that there are examples of gender bias in the book Pendidikan Agama Islam dan Budi Pekerti SMP class VII K-13 in Chapter XIII which shows a picture of two men wearing military uniforms in the defense and security sector, further emphasizing that the territory of women is in the domestic sector. In addition, the book Pendidikan Agama Kristen dan Budi Pekerti SMP for Class VII K-13 in Chapter III shows women (mothers) are caring for and taking care of children.

An educational institution that has achieved gender equality and justice is SMP Negeri 15 Yogyakarta. One of the visions of SMP Negeri 15 Yogyakarta is "the realization of a cultured gender responsive school" and is further elaborated through its mission "to balance the specific needs of students (gender responsive)". SMP Negeri 15 Yogyakarta is one of the schools that implements a gender responsive school which was initiated in 2015. Based on the description above, researchers are interested in conducting research on gender responsive schools in social studies learning with the title "Implementation of Gender Responsive Schools in Social Studies Learning at SMP Negeri 15 Yogyakarta. "In order to know in depth 
how the teacher's efforts in implementing and instilling the value of gender justice and equality in gender responsive schools.

\section{Method}

This research is a research with a qualitative approach using descriptive research methods. This research was conducted at SMP Negeri 15 Yogyakarta. The subjects of this study were key informants being teachers and students. Data collection techniques using interviews, observation, and documentation. The data validity checking technique was carried out by triangulating the source. Data analysis using Miles and Huberman which was carried out interactively and continued continuously to completion, so that the data was saturated.

\section{Results And Discussion}

\section{a. Gender Responsive School Content Standards in Social Studies Learning}

Gender mainstreaming in education is a strategy developed to integrate gender into the education sector. Gender equality in education requires efforts to integrate gender materials in the curriculum. Gender responsive curriculum needs to take concrete steps, such as reviewing basic competency standards in content standards that can be integrated by gender responsive values in each subject and integrating these values into indicators or learning activities in the syllabus and lesson plans. According to the Directorate of Junior High School Development (2010: 9) states that gender responsive schools must include gender considerations in each learning component. This is done by SMP Negeri 15 Yogyakarta by incorporating gender material considerations in social studies learning in the syllabus and lesson plans, teaching materials, and learning media.

The syllabus and lesson plans made by social studies teachers at SMP Negeri 15 Yogyakarta are in the same format as other schools, but there are aspects that differentiate them from other schools, namely adding gender responsive values. Development of syllabus and lesson plans in social studies learning at SMP Negeri 15 Yogyakarta, namely replacing the word "student" with "learner" which aims to not be discriminatory and favor one gender and can cover all male and female students. According to Remiswal (2013: 22) states that gender-based education requires several requirements, including education that is not discriminatory.

The next aspect in the content standard is teaching materials. Teaching materials used in social studies learning at SMP Negeri 15 Yogyakarta use student books or textbooks and student worksheets. Supardi (2011: 179) states that textbooks that have been used in schools for learning have not been able to fully solve learning problems in every place, such as the social studies subject book at SMP Negeri 15 Yogyakarta, there are only a few sub-subjects that include gender responsive values. Apart from student books, there are also student worksheets prepared by the social studies teacher. The worksheets are made on the basis of student books, which do not all meet learning needs. The content of the material in this worksheet contains illustrations and materials that will be taught in social studies learning. This worksheet was created by including the values of gender equality and justice as the vision and mission of the school. Worksheets at the same time can be used to measure the level of knowledge of students during social studies learning on certain materials. 
In addition, in the content standard there are aspects of learning media. The development of media in social studies learning at SMP Negeri 15 Yogyakarta is actually mediocre and not that prominent. Social studies teachers only develop learning media that are almost the same as other schools, namely showing pictures, showing films, and powerpoints. According to Roziqoh\&Suparno (2014: 89) states that efforts to improve gender equality and justice in education can be developed through formal and non-formal education by creating learning conditions that respect gender equality and criticizing learning media that are still gender biased, so that the value of gender equality can be internalized until the end of life.

What distinguishes the media in social studies learning at SMP Negeri 15 Yogyakarta from other schools is the content of the learning media used, for example how to illustrate the role of a mother who does not only work in the kitchen but now she can work in a factory. This change is seen from social changes, now these changes occur in the pattern of mother-father roles, where mothers are freer to work outside such as fathers and fathers taking turns taking care of household needs such as mothers. In addition to these illustrations, there are screenings of pictures and films during the kingdom era that exemplify a queen who could lead a kingdom. This is what distinguishes the media in social studies learning at SMP Negeri 15 Yogyakarta from other schools and is not obtained from other schools.

\section{b. Process Standards (Learning Process) for Gender Responsive Schools in Social Studies Learning}

The learning process for gender responsive schools in social studies learning is not just about giving and receiving learning in the classroom. However, in the gender responsive social studies learning process, there are several aspects that must be considered, such as learning methods and models (gender responsive learning activities), gender responsive classroom management, and assignments that do not differentiate.

Gender-responsive learning process activities in social studies learning at SMP Negeri 15 Yogyakarta must pay balanced attention to the special needs of male and female students. According to Wibowo (2010: 193) states that gender responsive learning requires teachers to pay attention to various approaches that meet the principles of gender equality and justice through a process of learning steps. Learning must be gender responsive because learning is a process of internalizing values about good and bad, what is and isn't, what should be done and what should not be done.

Social studies learning activities are divided into several learning steps, such as opening, core activities, and closing. The steps of learning activities, in this case social studies learning, can include gender responsive values. Gender responsive values in social studies learning at SMP Negeri 15 Yogyakarta are more often included in the core learning activities, because there is a process of group division, question and answer, and presentation. In addition, social studies teachers also include it in the perception and motivation section.

Creating gender responsive social studies learning conditions to be effective and efficient requires the development of methods in learning. The learning method developed must pay attention to the conditions of male and female students. Therefore, social studies teachers must be able to use learning methods that suit the needs of male and female students. The use of gender-responsive learning methods in social studies learning at SMP Negeri 15 Yogyakarta, namely using the discussion method. Discussion learning methods can facilitate students. men and women in a group that aims to mix male and female students, reduce the dominance of one sex, and social studies teachers can also provide equal opportunities to students.

According to Remiswal (2013: 27) states that the implementation of gender responsive education must be non-sexist, encourage critical attitudes, not discriminate, and take place democratically. The method in the social studies learning process developed by the social 
studies teacher at SMP Negeri 15 Yogyakarta has applied the principle of non-sexist learning. Non-sexist social studies learning at SMP Negeri 15 Yogyakarta, such as the formation of discussion groups that do not differentiate between male and female students and within one group must blend into one, there are male and female students. The social studies teacher also allows all male and female students to become group leaders. This is to eliminate the stereotype that the chairman or leader must be male.

Social studies learning at SMP Negeri 15 Yogyakarta that takes place is not discriminatory seen in the learning model it uses. Social studies learning uses a classical learning model which is more suitable for implementing gender equality in social studies learning compared to the expository learning model, because the classical learning model encourages male and female students to work together without subordination and certain gender marginalization. The classical learning model in social studies learning also encourages students who are less smart and smart to compete actively and skillfully, because each student has the same and equal rights without any discrimination.

The gender responsive learning process at SMP Negeri 15 Yogyakarta also takes place in a democratic way in managing its classrooms. Class management at SMP Negeri 15 Yogyakarta is one very important aspect of the learning process in the classroom. Class management is important because it can be the most important factor to hone the motivation and potential of students in participating in class management. Male and female students have equal rights in realizing gender responsive classes. Gender-responsive classroom management at SMP Negeri 15 Yogyakarta is implemented in the form of class management from the chairperson, secretary, treasurer, to other sections which are democratically elected and pay attention to the values of gender equality, for example, chairperson 1 female student then chairman 2 or the representative must be a male student.

In addition, the implementation of the social studies learning process that is gender responsive includes assignments that do not differentiate between male and female students. Social studies teachers in assigning students the same and equal way so that there is no domination by one particular gender. This assignment in social studies learning aims to encourage students' critical attitudes towards the given assignment. Students are expected to actively ask questions, make assumptions or opinions, gather information, and be able to draw conclusions.

\section{c. Structuring Gender Responsive School Classrooms in Social Studies Learning}

Facilities and infrastructure are some of the factors that affect the quality of education and are a determining aspect in supporting the process of implementing gender responsive schools in social studies learning at SMP Negeri 15 Yogyakarta. SMP Negeri 15 Yogyakarta is a school that has complete and adequate facilities and infrastructure to support the implementation of a gender responsive school that takes into account the specific needs of all genders. One of the indicators of facilities and infrastructure that supports the implementation of gender responsiveness in social studies learning is the arrangement of classrooms.

The classroom is a room that functions as a place for the process of teaching and learning activities. There are several aspects to designing a gender-responsive classroom, such as table design, seating, and pictures of class figures. According to Wibowo (2010: 193), one of the indicators that can create a gender responsive school in learning is the arrangement of gender responsive classrooms. Classroom arrangement is very important to increase the effectiveness of the learning process. Gender-responsive classroom arrangement needs to respond to the specific needs and feasibility of male and female students.

The arrangement of classrooms at SMP Negeri 15 Yogyakarta has a characteristic genderresponsive classroom concept, including the design of a study table for female students that 
has a cover on the front. The existence of a table cover on the front serves as a protector for female students wearing skirts or shorts. The table cover on the front can also maintain the safety and comfort of students and teachers in the process of teaching and learning activities.

Another characteristic of classroom arrangement in social studies learning at SMP Negeri 15 Yogyakarta is seating. The seats of students are arranged alternately front-back and rightleft according to the rotation applied in each class which aims to provide equal access and participation of male and female students in the process of teaching and learning activities in class. In addition, the arrangement of classrooms at SMP Negeri 15 Yogyakarta requires the proportion of heroes in the classroom. Persuasive pictures of heroes in this class are used as a form of socialization, education, and to provide inspiration and enthusiasm for male and female students to emulate their role models.

\section{d. Gender Responsive School Assessment Standards in Social Studies Learning}

According to Permendiknas Number 20 of 2007 concerning Education Assessment Standards states that one of the principles of assessment is the existence of a fair element. Fair in the sense that the assessment does not benefit or harm students because of special needs, differences in religious, ethnic, cultural, cultural, social and economic status and gender.

Gender responsive school assessment standards in social studies learning at SMP Negeri 15 Yogyakarta are carried out by taking into account the nature of men and women in order to create a fair and equal assessment of gender, for example female students who are experiencing pain during menstruation / illness during final semester exams or daily tests. These students can submit a schedule of tests or follow-up tests to the social studies teacher to be given a replacement day for the exam or follow-up tests. In addition, the material for exam questions or daily tests in social studies learning that is given does not tend to benefit either gender and the assessment process is carried out objectively for male and female students.

\section{e. Supporting and Inhibiting Factors for the Implementation of Gender Responsive Schools in Social Studies Learning}

The implementation of gender responsive schools in social studies learning at SMP Negeri 15 Yogyakarta is inseparable from the driving factors that can support its implementation. The driving factor arises because it is based on the relationship between social studies subjects and social life in society. Social studies learning in this case plays an important role in encouraging it, because social studies learning is dynamic and can adapt to changes in community development. According to Wijayanti\&Wulandari (2016: 88) states that the social studies subject is an integration and simplification of various social science disciplines which are arranged systematically, comprehensively, and integrated, and it is hoped that students can analyze the condition of society and be able to solve problems in everyday life.

Social studies learning at SMP Negeri 15 Yogyakarta integrates it with gender material with the aim that students can analyze the social conditions of society and provide provisions for students as social beings who in the future will go directly to the community to solve problems in everyday life without discrimination of access and participation. against either gender.

The social life that students will live in can later bring about gender equality in society. Realizing gender equality in society is certainly not easy and there are several factors that influence it, such as intelligence, responsibility, and how students will adapt to society. Therefore, social studies learning plays an important role in realizing the vision and mission of gender responsive schools in SMP Negeri 15 Yogyakarta.

The implementation of gender responsive schools in social studies learning at SMP Negeri 15 Yogyakarta has encouraged and supported both aspects of learning tools, learning processes, and facilities. However, behind these driving and supporting factors, there are 
factors that hinder in realizing gender equality in social studies learning, for example there is still bullying between students in social studies learning.

Bullying is an action or action carried out by humans, both individually and collectively, which is a repeated attack physically, verbally, psychologically, or socially. Bullying that occurred at SMP Negeri 15 Yogyakarta was verbal bullying that was only carried out by certain students, in the form of mocking or making fun of each other and not until there was physical bullying that led to acts of violence or oppression. In addition, there are efforts made by social studies teachers to minimize bullying when learning in class, namely trying their best to provide advice when learning and providing socialization to students about the dangers of bullying.

\section{Conclusions}

The implementation of gender responsive schools in social studies learning at SMP Negeri 15 Yogyakarta has four standard components, namely (1) gender responsive school content standards in social studies learning, (2) gender responsive school process standards in social studies learning, (3) classroom structuring standards gender responsive schools in social studies learning, and (4) gender responsive school assessment standards in social studies learning.

Gender responsive school content standards in social studies learning at SMP Negeri 15 Yogyakarta consist of three aspects, namely (1) gender-based syllabus and lesson plans, (2) teaching materials that can be accessed by men and women, and (3) learning media who are not gender biased. Gender responsive school process standards in social studies learning at SMP Negeri 15 Yogyakarta consist of five aspects, namely (1) learning methods provide equal opportunities for men and women, (2) learning models that encourage students to be active and skilled, ( 3 ) gender responsive classroom management to hone the motivation and potential of students in participating in class management, (4) assignments given to students are the same and equal so that there is no domination by one particular gender, and (5) social studies learning activities which can include gender responsive values.

The standard for structuring classrooms for gender responsive schools in social studies learning at SMP Negeri 15 Yogyakarta consists of three aspects, namely (1) the design of the table used, most of the closed front, is gender responsive, (2) the seats of the students are alternately arranged to provide equal access. and the participation of male and female students in the teaching and learning process in the classroom, and (3) the pictures of hero figures must contain male and female heroes that aim to motivate students in order to provide inspiration and enthusiasm for emulating his personality. Gender responsive school assessment standards in social studies learning at SMP Negeri 15 Yogyakarta are carried out by taking into account the nature of men and women in order to create a fair and equal assessment of gender.

There are two factors in implementing gender responsive schools in social studies learning at SMP Negeri 15 Yogyakarta, namely driving factors and inhibiting factors. The driving factor is based on the relationship between social studies subjects and social life in society. The social life that students will live in can later bring about gender equality in society. The inhibiting factor is in the form of bullying between students in social studies learning, such as making fun of each other or making fun of each other and there is no physical bullying that leads to acts of violence or oppression. However, to minimize these inhibiting factors, social 
studies teachers always provide advice and outreach to students in every lesson regarding the impact of bullying.

\section{References}

[1] Amir, Z, Gender Perspective in Mathematics Learning. MarwahJournal,12 (1), 14-31., 2013.

[2] Bps.go.id.(2019). Title is available at https://www.bps.go.id/dynamictable/2018/08/15/1566/-ipgrata-rata-lama-sekolah-rls-menurut-provinsi-dan-jenis-kelamin-2010- 2018.html accessed on 29 November 2019 at 14.10 WIB.

[3] Directorate of Junior High School Development. (2010). Guidelines for Implementing Gender Based Education for Junior High Schools. Jakarta: Ministry of National Education.

[4] Directorate of Early Childhood Education, Nonformal \& Informal. (2014). Gender Responsive Education Indicators. Jakarta: Ministry of Education and Culture.

[5] Ministry of Education and Culture. (2003). RI Law Number 20, 2003, concerning the National Education System.

[6] Miles \& Huberman. (2014). Qualitative Data Analysis. (TjetjepRohendiRohidi Translation). Jakarta: University of Indonesia (UI-Press).

[7] Muawanah, E. (2009). Gender Education and Human Rights. Yogyakarta: Terrace.

[8] Murfi, A. (2014). Bias Gender dalamBuku Teks Pendidikan Agama Islam dan Kristen. Jurnal Pendidikan Islam, 3(2), 267-287.

[9] Nugroho, R. (2008). Gender dan StrategiPengarus-utamaannya di Indonesia. Yogyakarta: Pustaka Pelajar.

[10] Remiswal. (2013). MenggugahPartisipasi Gender di LingkunganKomunitasLokal. Yogyakarta. Grahallmu.

[11] Roziqoh. (2013). Pendidikan Berperspektif Gender pada Anak Usia Dini. Jurnal Pendidikan dan Pemberdayaan Masyarakat, 1(1), 86-100.

[12] Sugiyono, MemahamiPenelitianKualitatif. Bandung: Alfabeta, 2009.

[13] Supardi. (2011). Dasar-Dasar IlmuSosial. Yogyakarta: Ombak

[14] Wibowo, DE (2010). SekolahBerwawasan Gender. JurnalMuwazah, 2(1), 189-196.

[15] Wijayanti, AT \&Wulandari, $\quad$ T. . PersepsiPesertaDidiktentangImplementasiPendekatanSaintifikdalamPembelajaran IPS di SMP se-Kecamatan Kretek, Bantul. JIPSINDO, 3(1), 78-100. 